Boston University School of Law

Scholarly Commons at Boston University School of Law

Faculty Scholarship

$6-2003$

\title{
The Economics of Litigation and Arbitration: An Application to Franchise Contracts
}

Keith N. Hylton

Boston University School of Law

Christopher R. Drahozal

Follow this and additional works at: https://scholarship.law.bu.edu/faculty_scholarship

Part of the Contracts Commons, Law and Economics Commons, and the Litigation Commons

\section{Recommended Citation}

Keith N. Hylton \& Christopher R. Drahozal, The Economics of Litigation and Arbitration: An Application to Franchise Contracts, in 32 Journal of Legal Studies 549 (2003).

Available at: https://scholarship.law.bu.edu/faculty_scholarship/770

This Article is brought to you for free and open access by Scholarly Commons at Boston University School of Law. It has been accepted for inclusion in Faculty Scholarship by an authorized administrator of Scholarly Commons at Boston University School of Law. For more information, please contact lawlessa@bu.edu. 


\section{HEINONLINE}

DATE DOWNLOADED: Sat Sep 24 19:37:54 2022

SOURCE: Content Downloaded from HeinOnline

Citations:

Bluebook 21st ed.

Christopher R. Drahozal \& Keith N. Hylton, The Economics of Litigation and

Arbitration: An Application to Franchise Contracts, 32 J. LEGAL Stud. 549 (2003).

ALWD 7th ed.

Christopher R. Drahozal \& Keith N. Hylton, The Economics of Litigation and

Arbitration: An Application to Franchise Contracts, 32 J. Legal Stud. 549 (2003).

APA 7th ed.

Drahozal, C. R., \& Hylton, K. N. (2003). The economics of litigation and arbitration: an application to franchise contracts. Journal of Legal Studies, 32(2), 549-584.

Chicago 17th ed.

Christopher R. Drahozal; Keith N. Hylton, "The Economics of Litigation and

Arbitration: An Application to Franchise Contracts," Journal of Legal Studies 32, no.

2 (June 2003): 549-584

McGill Guide 9th ed.

Christopher R. Drahozal \& Keith N. Hylton, "The Economics of Litigation and

Arbitration: An Application to Franchise Contracts" (2003) 32:2 J Legal Stud 549.

AGLC 4th ed.

Christopher R. Drahozal and Keith N. Hylton, 'The Economics of Litigation and

Arbitration: An Application to Franchise Contracts' (2003) 32(2) Journal of Legal

Studies 549

MLA 9th ed.

Drahozal, Christopher R., and Keith N. Hylton. "The Economics of Litigation and Arbitration: An Application to Franchise Contracts." Journal of Legal Studies, vol. 32, no. 2, June 2003, pp. 549-584. HeinOnline.

OSCOLA 4th ed.

Christopher R. Drahozal \& Keith N. Hylton, 'The Economics of Litigation and

Arbitration: An Application to Franchise Contracts' (2003) 32 J Legal Stud 549

Provided by:

Fineman \& Pappas Law Libraries

-- Your use of this HeinOnline PDF indicates your acceptance of HeinOnline's Terms and Conditions of the license agreement available at

https://heinonline.org/HOL/License

-- The search text of this PDF is generated from uncorrected OCR text.

-- To obtain permission to use this article beyond the scope of your license, please use:

Copyright Information 


\title{
The Economics of Litigation and Arbitration: An Application to Franchise Contracts
}

\author{
Christopher R. Drahozal and Keith N. Hylton
}

\begin{abstract}
If we define the deterrence benefits from contract enforcement to be avoided harms net of avoidance costs, we should expect contracting parties to choose the dispute resolution forum that provides the greatest difference between deterrence benefits and dispute resolution costs. We apply this framework to franchise contracts and conduct an empirical analysis of the determinants of arbitration agreements among franchising parties. Although it is obvious that contracting parties have an incentive to choose arbitration to reduce dispute resolution costs, there have been no studies of the importance of deterrence concerns. We examine the deterrence hypothesis and find a great deal of support for it. Our results suggest that deterrence factors outweigh litigation costs in the design of dispute resolution agreements. We find that the probability of arbitration is significantly higher when the parties rely on implicit contract terms for governance and compliance with those terms is difficult to ensure.
\end{abstract}

\section{INTRODUCTION}

This paper combines two largely unconnected strands in the literature, the economics of litigation and the economics of franchise contracts, in an effort to shed new light on both. The economics of litigation literature has focused on incentives to litigate a dispute-that is, ex post incentives. The literature on the economics of franchise contracts, on the other hand,

CHRISTOPHER R. DRAHOZAL is at the University of Kansas. KEITH N. HYLTON is at Boston University. We thank Bob Bone, Vic Khanna, Michael Meurer, Steve Ware, Manuel Utset, and participants in workshops at Boston University and the University of Kansas for helpful comments. We thank Frank Easterbrook, Dan Klerman, and Warren Schwartz for very helpful comments during our presentation of a draft of this paper at the 2001 American Law and Economics Association meeting. We also thank the referee for several valuable suggestions. Yulia Rodionova provided excellent research assistance. 
has attempted to explain the shape of franchise agreements as responses to the ex ante shirking and free-riding incentives observed in the franchise relationship. Relatively little theoretical or empirical work in this area has looked at how the choice of dispute resolution forum responds to the classic incentive problems in franchising. ${ }^{1}$ This paper takes a step toward filling gaps in the litigation and contracts literature by examining how the decision to commit disputes to arbitration responds to ex ante incentives in franchising.

Contracting parties can choose, before any disputes arise, whether to resolve all or a subset of their disputes in court or through arbitration. We should expect such predispute agreements to be designed to minimize the costs of their relationship. Specifically, if we define the deterrence benefits (or governance benefits) to be avoided harms net of avoidance costs, we should expect contracting parties to choose the dispute resolution forum that provides the greatest difference between deterrence benefits and dispute resolution costs for every type of dispute. ${ }^{2}$ For contracting parties, the harms avoided through superior governance generally can be classified as losses due to breach of either explicit or implicit contract terms.

We apply this framework to franchise contracts and conduct an empirical analysis of the determinants of arbitration agreements among franchising parties. Although it is obvious that contracting parties have an incentive to choose arbitration in order to reduce dispute resolution costs, there have been no studies of the importance of deterrence concerns. We examine the deterrence hypothesis here and find a great deal of support for it. Our results suggest that deterrence concerns outweigh litigation costs in the design of dispute resolution agreements. In the franchising literature, the connection between implicit and explicit contract terms has been explored in depth. We find that the probability of arbitration is significantly higher when the parties are likely to rely on implicit terms for governance and compliance with those terms is difficult to ensure.

This study suggests a rather complex relationship among dispute res-

1. The exception is Williamson $(1985$, p. 71$)$, who stresses the "continuity" role played by an agreement to commit disputes to arbitration.

2. This paper relies on the framework and terminology set out by Hylton (2000). However, Shavell's (1995) analysis anticipates several of the theoretical points in that article and in this one. In particular, Shavell shows that contracting parties can induce good performance and thereby raise the value of the contract by switching to a more accurate dispute resolution forum. 
olution provisions, incentive control provisions, and contract sanctions. The choice of dispute resolution forum affects not only ex ante incentives and dispute resolution costs. It also affects contracting costs, since parties are more likely to leave contract provisions vague, opting for relational governance (Macneil 1978), when they have chosen a dispute resolution forum that can be trusted to reach value-maximizing results. On the other hand, the parties may prefer explicit contract terms if they have a high degree of confidence regarding the interpretation of those terms in court.

We find that franchisors in states with franchisee protection statutes are less likely (all else equal) to provide for arbitration than are other franchisors. This suggests, at a minimum, that franchisors have not viewed arbitration as a forum in which arbitrators would disregard or misapply protection statutes to their benefit. The result is consistent with the hypothesis that parties constrained by franchisee protection statutes shift toward greater contractual explicitness in order to restore credibility to the sanctioning threat.

Section 2 sets out the basic theory of arbitration agreements and applies the theory to the franchising context. It begins with a framework that applies equally well to torts and to contracts and then extends the framework by incorporating the roles of contractual explicitness and alternative contract sanctions. Section 3 sets out the empirical analysis, based on a sample of 75 franchise agreements. Section 4 concludes.

\section{ECONOMICS OF LITIGATION AND ARBITRATION}

\subsection{Incentives and Contract Enforcement}

This section explores the economic motivations behind predispute arbitration agreements. We will assume that the parties can contract over the type of dispute resolution forum. Their options are the "default" litigation regime, which involves bringing suit in a court, and an arbitration regime, which may provide different levels of damage awards and dispute resolution costs.

2.1.1. General Setting. This discussion assumes that transaction costs prevent the parties from contracting initially over the level of care, effort, or forbearance exercised in their relationship. Given this, they will choose the private enforcement regime that best governs incentives. We 
assume there are no third-party effects, so the level of forbearance that is preferable between the contracting parties is also socially preferable.

There are two parties, the potential plaintiff and the potential defendant (for simplicity, Plaintiff and Defendant), both of whom are risk neutral. Defendant decides ex ante whether to forbear from an act that could harm Plaintiff. If Plaintiff is harmed, he will bring a claim for compensation against Defendant. This framework applies equally to tort and contract settings. ${ }^{3}$ In the tort setting, the potential defendant decides whether to take care, and his decision affects the probability that Plaintiff suffers harm. ${ }^{4}$ In the contract setting, Defendant decides whether to breach a term of the contract or to reduce his level of effort (breaching an implicit term). Let

$x=$ Defendant's forbearance cost,

$\nu=$ harm to Plaintiff,

$d=$ damage award,

$q=$ probability of harm to Plaintiff if Defendant does forbear,

$p=$ probability of harm to Plaintiff if Defendant does not forbear,

$\alpha=$ Plaintiff's dispute resolution cost, and

$\beta=$ Defendant's dispute resolution cost.

Plaintiff will bring a claim for compensation if his expected damage award exceeds his dispute resolution cost, $d>\alpha$. For simplicity, we will assume this holds. Since Defendant will minimize his total private cost, he will forbear if and only if his forbearance cost is less than his marginal expected liability,

$$
x+q(d+\beta)<p(d+\beta) \text {. }
$$

Forbearance is socially desirable when Defendant's forbearance cost is less than the marginal social cost of his act,

$$
x+q(\nu+\alpha+\beta)<p(\nu+\alpha+\beta) .
$$

It follows that Defendant's incentive to forbear is socially optimal if and only if $d=v+\alpha$ and the optimal damage level is $v+\alpha$. As long as the damage level fails to cover Plaintiff's loss and litigation cost, potential defendants will fail to forbear in some instances in which forbearance

3. The simple model in this section is a version of that in Shavell (1982).

4. This framework applies in the torts setting to the case in which the potential defendant and the potential plaintiff can enter into a dispute resolution agreement before an accident occurs. For example, many nuisance, trespass, and products liability cases fall in this category. Obviously, traffic accidents, which typically involve strangers, do not fit within this category. 
is socially desirable. Conversely, if the damage level exceeds the sum of Plaintiff's loss and litigation cost, potential defendants will forbear in some instances in which forbearance is not socially desirable. The former case generates "underdeterrence" costs, the latter "overdeterrence" costs.

If potential plaintiffs were not allowed to bring claims, potential defendants would not forbear. Thus, the net social benefit from the dispute resolution forum is

$$
(p-q) v-x-q(\alpha+\beta) .
$$

This is the difference between the deterrence benefit, in terms of avoided losses net of avoidance costs, and the expected dispute resolution cost. If this difference is negative, social welfare could be improved by prohibiting litigation (Shavell 1982). To simplify, we will assume this difference is positive. $^{s}$

Consider the incentives for the parties to commit their disputes to arbitration rather than remain in the litigation regime. The option to commit to resolve disputes within an arbitral forum allows the parties some choice over the expected damage award and the dispute resolution costs. They will choose arbitration over the litigation regime whenever switching to the arbitration regime enhances the net benefits from the dispute resolution forum. Thus, the parties will choose to commit to arbitration when the difference between the deterrence benefit and expected dispute resolution cost is larger under arbitration than under the litigation regime (Hylton 2000).

Examining (2) and (3), one can see several ways in which the difference between the deterrence benefit and dispute resolution cost can be enhanced under an arbitration regime. Consider the following:

Underdeterrence in the Litigation Regime. Suppose that damages in the litigation regime are less than the optimal level-that is, $d<v+\alpha$. In this case, the level of forbearance among potential defendants is less than the optimal level. Assuming that dispute resolution costs are the same in the arbitration regime, the parties can minimize underdeterrence costs by adopting an arbitration regime in which damages are set at the optimal level $(d=v+\alpha)$. It follows that if $d$ is so small in the litigation regime that no victim has an incentive to sue, or if courts tend to err in the direction of failing to award damages in the litigation regime, the

5. If this condition does not hold, then it may be desirable to reduce the optimal damage level in order to discourage some lawsuits. See Polinsky and Rubinfeld (1988); Hylton (2002). The precise level of the optimal damage award is not important for this study. 
parties can gain jointly by committing to an arbitration regime in which expected damages awards are closer to the optimal level.

Overdeterrence in the Litigation Regime. Suppose damages in the litigation regime exceed the optimal level $(d>v+\alpha)$. Since the level of forbearance among potential defendants would exceed the optimal level, the parties can enhance deterrence benefits by committing to an arbitration regime in which the damage award is closer to the optimal level. Thus, if because of the risk of a large punitive verdict, the expected damages award in the litigation regime exceeds the optimal level, the parties have an incentive to commit to an arbitration regime that caps damages at a level closer to the optimal level. Similarly, if courts are likely to award damages in inappropriate cases, the parties will have an incentive to switch to arbitration.

Reducing Dispute Resolution Costs. It is clear from (3) that if dispute resolution costs are lower in the arbitration regime and the deterrence benefit is the same, the parties will prefer the arbitration regime. Of course, in many instances there will be a connection between the two. When high litigation costs effectively bar some victims from bringing suit, committing to arbitration can simultaneously enhance the deterrence benefit and reduce dispute resolution costs. In other cases, the parties will trade off a reduction in the deterrence benefit for an even greater reduction in the dispute resolution cost. ${ }^{6}$ The key factor in determining the preference for arbitration is the difference between the deterrence benefit and total dispute resolution cost. Thus, the parties may prefer an arbitration regime in which dispute resolution costs are substantially higher if the incremental deterrence benefit is large enough.

\subsubsection{Low-Transaction-Costs Setting: Contract Terms as Substitutes and}

Complements. So far, we have assumed that transaction costs prevent the parties from contracting directly over the level of forbearance or effort. This assumption should be relaxed in the contract setting. Contracting parties often write rules into their agreements that directly regulate the other party's conduct. Transaction costs obviously do not prevent them from doing this.

There are other types of transaction costs, however, that might discourage contracting parties from trying to write rules that directly

6. For example, parties may provide for less discovery in arbitration, potentially reducing the accuracy of the result, because the savings in dispute resolution costs exceed the possible reduction in deterrence benefits. See Drahozal (2001). 
regulate ex ante incentives. In some settings, it is extremely costly for the parties to specify the level of effort required, and there is a correspondingly high probability that a court will misinterpret the contract. These are cases in which the level of effort is "noncontractible." In order to avoid errors in court that would result in suboptimal deterrence, the parties may prefer to commit disputes involving these matters to arbitration.

As a general rule, contractual explicitness-that is, setting out rules that directly regulate ex ante incentives-should serve as a substitute to arbitration. The reason is that explicit rules minimize the likelihood that a court will err in a way that generates over- or underdeterrence costs. In the case of a term that serves as a substitute, its presence implies that the parties will have a lower demand for arbitration. However, some explicit contract terms may serve as complements to arbitration. If a term serves as a complement, its presence implies that the parties will have a greater demand for arbitration. In particular, where the risk of a court misinterpreting or failing to enforce a particular term is high (for example, a cap on damages), the term is likely to serve as a complement to an arbitration agreement.

Summing up, whether an explicit term serves as a substitute or complement to arbitration depends on its relative accuracy of application and its relative probability of enforcement in court. Contractual explicitness reduces any accuracy advantage that arbitration could provide, making explicit terms a substitute to arbitration in most cases. The exception to this rule is when the probability of enforcement in court of a particular explicit term is low. In this case, the term may serve as a complement to arbitration. ${ }^{7}$

\subsection{Arbitration in the Franchise Setting}

2.2.1. Deterrence Issues in Arbitration. The foregoing can be applied to franchising arrangements. Franchising is a form of business organization

7. This framework may explain the conclusion of Lisa Bernstein's analysis of trade association arbitrators; see Bernstein (1996). Bernstein found that even though those arbitrators had substantial expertise in the subject matter, they seemed to decide cases in a formalist fashion based on explicit contract provisions and codified trade rules. They did not seem to rely on their industry expertise to enforce implicit terms in the parties' contracts. Although it is hard to say whether expertise plays an important role in any contract interpretation setting, our framework could explain the reported conduct of Bernstein's arbitrators as a response to low enforcement probabilities in the relevant courts. In any event, there are other settings-notably, international commercial arbitration-in which arbitrators are willing to enforce implicit as well as explicit contractual terms. See Drahozal (2000). 
that economizes on monitoring costs in an enterprise with geographically dispersed outlets. ${ }^{8}$ The franchisor permits the franchisee to use its trademark and business model and provides training and guidance in running the business. In exchange, the franchisee pays the franchisor ongoing royalties and is responsible for various upfront costs. A key difference between company-owned outlets and franchised outlets is that managers are paid a salary while franchisees receive a share of the profits of the franchise. By making the franchisee a residual claimant, the franchisor reduces the need to monitor the franchisee, since the franchisee bears much of the cost of his own shirking.

There is a fundamental incentive divergence under franchising that results in the franchisee investing too little effort in maintenance of brand capital. In the presence of a population of mobile consumers who patronize other units in the franchise network, an individual franchisee will not capture the full benefits from increasing his level of effort. The benefits of such efforts are shared with the franchisor and with other franchisees in the network. As a result, the franchisee will tend to exert too little effort from the franchisor's perspective (Rubin 1978; Brickley and Dark 1987; Brickley 1999). Moreover, the franchisee has an incentive to free ride on the brand's capital, since he captures the full savings from reducing his effort level, while the devaluation of brand capital is shared by other units in the network (Rubin 1978).

There are several factors that constrain the franchisee's incentive to shirk or free ride. First, the franchisor will attempt to control the franchisee's incentives through various structural and contractual incentive alignment devices. One structural device is the ownership of a large percentage of outlets in the network. Since company-owned outlets are less likely to free ride, their presence in the network reduces the overall level of shirking. This enables the franchisor to allocate his monitoring effort toward franchised units. It may also enhance franchisee incentives by providing a form of "yardstick competition" with franchised outlets." Company-owned outlets serve as a benchmark for comparison to franchised units. ${ }^{10}$

Contractual incentive alignment devices are more common. Franchise

8. The economic analysis of franchise contracts starts with Rubin (1978). For some of the theoretical literature building on Rubin, see Mathewson and Winter (1985); Lafontaine and Raynaud (2002).

9. On the economics of yardstick competition generally, see Shleifer (1985).

10. For a discussion of the informational benefits of partial integration, see Michael (2000). 
contracts include provisions that attempt to regulate the franchisee's effort in service and brand promotion. For example, many franchise contracts include restrictions on passive ownership, area development plans, and mandatory advertising provisions.

Second, the franchisor will often monitor franchisees to ensure compliance with explicit contractual terms and the franchisor's expectations. Franchise contracts often include provisions that authorize the franchisor to monitor, such as the right to audit and to inspect the franchisee periodically.

Third, repeat business to an individual unit serves as a constraining factor. A high level of repeat business allows the franchisee to reap the rewards of his efforts and also forces him to bear the costs of his shirking (Brickley 1999). Thus, if the size of the franchise network is small, or the units are far apart, each individual unit will enjoy a relatively large amount of repeat business and will therefore have a greater concern for the longterm costs of shirking.

Fourth, sanctions for failing to comply with explicit and implicit contractual terms are employed. The most obvious sanctions are termination and litigation. Termination is costly to the franchisee to the extent that it causes him to lose a stream of "quasi rents." As Klein and Saft $(1985$, p. 352) note, "[T] $\mathrm{T}$ he franchisor may create quasi rents by requiring the franchisee to invest in specific (not fully salvageable) production assets on which the franchisee is earning a normal rate of return but which, on termination, imply a capital cost penalty." The creation of quasi rents in a franchise relationship is equivalent to having the franchisee post a bond that he forfeits on termination. However, the bond posted by the franchisee gives the franchisor an incentive to act opportunistically-to appropriate the stream of quasi rents. ${ }^{11}$

Short of termination, suing for breach of contract is the likely sanction imposed on a shirking franchisee. Parties may choose to resolve their disputes in arbitration or through litigation. One important difference between the two dispute resolution processes is their implications for the continuity of the relationship. According to Williamson (1985,

11. On opportunism and franchise contracts, see Hadfield (1990) and Lafontaine and Shaw (1999). Ordinarily, the franchisee relies on the franchisor's reputation as protection against such opportunism. A franchisor that acts opportunistically toward its franchisees will be less able to attract new franchisees in the future. However, as Klein $(1980$, p. 360) explains, "[T]his protective mechanism is limited by the relative importance of new franchise sales compared to the continuing franchise operation, that is, by the maturity of the franchise chain." 
p. 71), “[W] $[\mathrm{W}$ ereas continuity (at least completion of the contract) is presumed under arbitration machinery, that presumption is much weaker when litigation is employed."

Ultimately, the credibility and force of sanctions depend on the likelihood of their being upheld in a dispute resolution process. A termination decision can be challenged, possibly leading to an expensive judgment against the franchisor. Moreover, the sanctioning threat is an important component of the franchising relationship in settings in which the cost of monitoring is high and the level of repeat business to individual units low. The parties will have a strong incentive in this setting to opt for the dispute resolution forum in which the deterrence benefit is greatest.

2.2.2. The Choice between Arbitration and Litigation. Arbitration may be preferable to the franchising parties when it enhances the deterrence or governance benefit associated with contract enforcement. This may occur because the expected damages award in court is above or below the optimal level. In either case, a more accurate dispute resolution forum would be preferable to the parties because it would provide damage awards closer to the optimal level, which, in turn, reduces the costs from overdeterrence or underdeterrence. In other words, although there is a common view that high damage awards are good for franchisees and bad for franchisors, this is not necessarily true. Since the costs of overdeterrence are shared between the contracting parties, both are potentially better off in the dispute resolution forum in which damage awards are closest to the optimal level.

Arbitration offers the parties the opportunity to enter into a specialized dispute resolution forum in which industry experts rather than uninformed jurors evaluate the litigants' predispute conduct. Such a forum can provide important benefits in cases involving difficult-tospecify or noncontractible requirements and expectations. ${ }^{12}$ For example, compliance with expectations that the franchisee devote optimal effort to local promotion or customer service may be easier to evaluate accurately or to enforce in the arbitration regime than in the litigation regime. To the extent that the parties have greater confidence in the accuracy of the dispute resolution forum, they can afford to leave contractual provisions vague, saving contracting costs.

On the other hand, where contracts are clear and enforcement easy to obtain through the courts, the parties are unlikely to find a greater

12. On contractual incompleteness and expectations, see Hadfield (1990, pp. 946-48). 
deterrence benefit under arbitration. Indeed, arbitration may reduce the deterrence benefit if the parties are uncertain as to how the arbitral forum will interpret contractual terms. This is especially likely when the courts have already developed a body of gap-filling common-law rules that the parties find acceptable. For example, a provision governing money due under the contract is usually clear enough not to need the aid of industry experts in determining if breach has occurred. Reliance on easily enforceable, explicit contracts-backed up by a stable set of common-law rules-may explain why banks continue to enforce their debt contracts in ordinary courts rather than in arbitration forums, even though arbitration could cut their litigation expenses substantially. ${ }^{13}$

Consider an example: a dispute over the amount of effort a franchisee gives to his business. Franchisors sometimes include provisions in the franchise contract specifying the number of hours per week or the specific times the franchisee must spend working at his franchised unit (Brickley 1999). These provisions are designed to increase the franchisee's effort level by restricting his outside activities, thereby lowering the opportunity cost to the franchisee of exerting effort at his unit (Brickley 1999). In the absence of such a provision, it would be difficult to demonstrate to a jury that the franchisee violated implicit contractual terms regarding his level of effort. Even with such a provision, there are innumerable ways in which a franchisee could comply with the hours requirement and yet fail to exert an acceptable level of effort. For example, a franchisee required by contract to spend 40 hours per week at his unit could come in at off-peak hours or pursue other personal projects while at the unit. Given the difficulties in specifying and evaluating effort levels, an arbitration forum could provide substantial deterrence benefits to the parties by increasing the accuracy of contractual compliance assessments involving the franchisee's level of effort.

In addition to providing a specialized tribunal, there is another way in which arbitration may enhance accuracy in adjudication. Arbitrators have different incentives than judges in resolving disputes. Arbitrators are selected by the parties and are paid only when they hear a case. Judges, by contrast, are assigned randomly to cases and paid fixed salaries by the government. As a result, arbitrators compete for business and have an

13. Park (1998, pp. 215-16). We are aware of no solid empirical evidence proving that arbitration always reduces litigation expenses. Our point is that it should be possible for banks to design an arbitration regime for debt enforcement that is cheaper than the courts. 
incentive to resolve disputes so as to enhance the governance benefits net of dispute resolution costs to the contracting parties (Tullock 1980, pp. 127-33).

Finally, even if the arbitration forum provides no advantage in terms of accuracy, the parties may still prefer it to litigation when it reduces dispute resolution costs. Again, consider a provision that governs money due under the contract. Since it is easy to determine whether a breach has occurred, arbitration is unlikely to provide a greater degree of accuracy than courts. In spite of this, parties may still prefer arbitration if the reduction in dispute resolution costs is large.

We will use the expression "implicit terms" to refer to expectations that are difficult to specify ex ante and to evaluate ex post, such as the level of effort in service and advertising. Arbitration should provide substantial deterrence benefits in evaluating compliance with implicit terms. We will use the expression "explicit terms" to refer to expectations that can be specified precisely in the contract, such as an agreement regarding payment of money due, or an expectation based on the law, such as the franchisor's expectation that the franchisee will not infringe the trademark. Arbitration is unlikely to provide a deterrence benefit, compared with the litigation regime, with respect to the explicit terms. The parties are therefore likely to rely on litigation to enforce explicit terms.

This discussion suggests both "external" and "internal" factors as determinants of the probability of arbitration. The external factors are institutional features over which the parties have no control and that can be avoided by committing to arbitrate. For example, one external factor is residence in a forum in which punitive damages awards are unusually frequent. To the extent such factors generate excessive deterrence costs, the parties have a joint incentive to reduce their costs by committing to arbitration.

There are three internal factors that determine the probability of an arbitration agreement. One is the ratio of implicit to explicit terms in the franchise contract. As this ratio increases, the likelihood of arbitration should also increase, since the deterrence benefit from arbitration should be greater for implicit contractual terms. Second, the probability of a dispute and the amount at stake should be associated with a greater likelihood of arbitration, provided there are important implicit terms in the contract. If arbitration provides a deterrence advantage, this benefit will increase with the probability of a dispute as well as the amount at stake, which implies that the probability of arbitration will increase. In 
the franchise setting, the probability of a dispute is determined by the severity of the agency cost problem. In settings where the agency cost (or incentive divergence) problem is more severe, the probability of a dispute will be larger and so will the frequency of arbitration. The third determinant of the probability of arbitration is the dispute resolution cost. Arbitration is potentially cheaper than litigation. Thus, the parties have an incentive to choose arbitration in order to lower dispute resolution costs.

Since it is difficult to observe the ratio of implicit to explicit contract terms, the probability of a dispute, and dispute resolution costs, we will work with observable factors associated with these variables. Factors associated with each of the three general determinants should be positively related to the probability of arbitration. This has some specific implications.

First, factors associated with a reduced probability of dispute or greater reliance on contractual terms should be negatively related to the probability of arbitration. Any feature that increases the bargaining power of the franchisor relative to the franchisee should have this effect, since the franchisor should find it easier to ensure compliance with contractual terms as his bargaining power increases. The most important component of the franchisor's bargaining power is his threat to terminate. Since the likelihood of a dispute is relatively low in cases where the termination threat is credible, the incremental benefit from switching to arbitration should be correspondingly low. Thus, the probability of arbitration should be negatively related to the factors that enhance the credibility of the franchisor's termination threat.

Second, other contract terms play important roles as either substitutes or complements to an arbitration agreement. The franchisor will prefer to substitute toward explicit contractual terms if his termination threat is credible only, or more credible, in the presence of explicit contractual terms. Such substitution can occur by inserting more explicit governance terms in the franchise agreement or by choosing a jurisdiction that is more likely to enforce existing contractual terms. On the other hand, other contract terms may serve as complements in the sense that they are more likely to be enforced in an arbitral forum.

This framework may explain why certain disputes are explicitly excluded from arbitration provisions. For example, trademark disputes are often excluded from arbitration. The likely reason is that these disputes do not involve implicit terms-that is, difficult-to-assess aspects such as effort and quality. They involve matters of law that the courts have 
examined for many years and with respect to which have developed a body of enforceable rules and effective remedies. For such issues, the parties are unlikely to gain by removing them from the courts.

\section{EMPIRICAL ANALYSIS}

\subsection{Sample}

The sample consists of 75 franchises that have franchise agreements available for public review at the Minnesota Department of Commerce. ${ }^{14}$ Minnesota, like a number of other states, requires franchisors to file disclosure statements before selling franchises in the state. ${ }^{15}$ Generally, the filing consists of a Uniform Franchise Offering Circular (UFOC) and other materials, including a copy of the franchise agreement. ${ }^{16}$ The 75 franchises comprise most of the top-ranked franchises in Entrepreneur Magazine's Franchise 500 for $1999 .{ }^{17}$ The Franchise 500 seeks to identify "the best opportunities for entrepreneurs" on the basis of a variety of objective factors. ${ }^{18}$ We do not use the ranking in any quantitative analysis. The sample, however, effectively includes only established franchisors that are seeking new franchisees, which limits our ability to test for any relationship between franchisor opportunism and arbitration.

For each franchise in the sample, we collected a copy of the dispute resolution clause from the publicly available copy of the franchise agreement. In the typical case, the copy of the franchise agreement on file in Minnesota was the franchisor's standard form for all franchisees, with state-specific addenda containing changes required by various state regulatory regimes. We collected the data from the standard forms without regard to the provisions of the state-specific addenda. As a result, the

14. For a more detailed description of the sample, see Drahozal (2001).

15. Minnesota Statutes Annotated (West 1999, sec. 80C.02); see Federal Trade Commission (1999).

16. Minnesota Statutes Annotated (West 1999, sec. 80C.04(h)); Minnesota Rules (1997, secs. 2860.3800, 2860.3500(15)).

17. Entrepreneur Magazine (1999a); see also Kobayashi and Ribstein (1999, p. 344) (using Franchise 500 data to test the choice-of-law hypothesis).

18. Entrepreneur Magazine (1999b, 1999c) (ranking based on "objective quantifiable measures of a franchise operation," including financial strength and stability, size of system, years in business, length of time franchising, startup costs, litigation history, franchisee terminations, and whether financing is provided). 
fact that Minnesota regulates certain terms of franchise agreements should not significantly bias our results. ${ }^{19}$

Minnesota regulations require a separate filing whenever the franchisor offers a franchise with terms that "vary substantially" from the terms on file, ${ }^{20}$ which presumably discourages individually negotiated changes in the franchise terms. Thus, we have some confidence that the provisions we reviewed constituted the terms of franchises actually sold in Minnesota. For each franchise, we coded variables to reflect the presence or absence of an arbitration clause, as well as whether the franchise agreement sought to restrict punitive damages, imposed a time limit on filing claims, or provided for litigation or arbitration to take place in the state where the franchisor's home office was located. ${ }^{21}$

We classified each of the franchises in the sample as "high externality" or "low externality" following Brickley (1999, pp. 754-57). Highexternality franchises are those in industries with a relatively low frequency of repeat business (to a specific franchise unit). Brickley includes in this category auto and truck rentals and food service companies. Lowexternality franchises are those in industries with a relatively high frequency of repeat business. Brickley here includes auto product and service outlets, fitness centers, dry cleaners, lawn care companies, maid services, travel agencies, and hair-styling outlets. To fill out this variable for the franchises in our sample, we added motels and hotels to the highexternality category ${ }^{22}$ and video rental and other retail outlets, real estate

19. While the use of dispute resolution clauses taken from standard-form franchise agreements avoids bias from collecting the data in Minnesota, it may overlook some franchisor responses to state regulations. To the extent that the franchisor responds to franchisee protection statutes by use of state-specific addenda, those responses will not be reflected in our data. An arbitration clause is not likely to be included (or excluded) in a statespecific addendum, however, because of the conspicuous disclosures concerning arbitration required in the UFOC. See Drahozal (2001, pp. 722-23 and n.208). As a result, this is not a serious limitation on our results.

20. Minnesota Rules (1997, sec. 2860.1100)

21. Clauses that gave the franchisor the option of requiring litigation in its home state were treated the same as clauses that required the parties to litigate in the franchisor's home state.

22. Brickley (1999, p. 755 n.20) notes that the hotel and motel industry is "commonly considered 'nonrepeat." But he excludes such franchises from his sample because they are unlikely to have restrictions on outside activities of franchisees, which was one of the types of contract provisions he was studying. We face no similar constraint. 
brokerages, and providers of various business services to the lowexternality category. ${ }^{23}$

Additional data about the franchises come from the Entrepreneur Magazine Web site. For each of the franchises in the Franchise $500,{ }^{24}$ the site reported the number of franchised and company-owned units for the years 1996-98, the dates the franchisor began in business and began franchising, whether the franchisor permits part-time or homebased operation of the franchise, and the initial investment required of the franchisor. ${ }^{25}$ Although Entrepreneur Magazine considers the litigation history of franchisors in preparing the Franchise 500, it does not publish or otherwise make available that information. Instead, we use the urbanization rate of the state in which the franchisor's home office is located as a proxy for the litigation risk faced by the franchisor (Posner 1997 , p. 480). Finally, we rely on the list of states with franchisee protection statutes (those requiring cause for termination) compiled by Kobayashi and Ribstein (1999, p. 466 n.106).

\subsection{Regression Variables and Hypotheses}

3.2.1. Variables. The variables used in our probit regression analysis are set out in Table 1. The dependent variable, Arb, is a dummy variable that takes the value of one when the franchise agreement contains an arbitration clause. The independent variables can be grouped into three categories: contract terms, external, and internal. The "contract terms" variables include Location, Timelimi, and Puni, each of which reflects a

23. Brickley (1999, p. 756) suggests that "the relation between the incentives to free ride and repeat customers is less clear in companies that provide business-related services" because of possible spillovers involving national clients. Nonetheless, the repeat nature of the business (for example, management recruiting and commercial cleaning) should be such that the incentive of the franchisee to free ride is less than in high-externality franchises (that is, food service, vehicle rental, hotel, and motel franchises). Accordingly, we coded business service and commercial cleaning as low externality. But see Brickley (1999, p. 756), who argues that these industries were too ambiguous to classify.

24. The source of the data is UFOCs that franchisors provide to Entrepreneur Magazine.

25. The initial investment of the franchisee comes from Item 7 of the UFOC, which requires franchisors to disclose the amount of investment required in $(a)$ "real property, whether purchased or leased"; $(b)$ "equipment, fixtures, [and] other fixed assets"; $(c)$ "inventory required to begin operations"; $(d)$ "security deposits, utility deposits, business licenses, [and] other prepaid expenses"; $(e)$ "additional funds required by the franchisee before operations begin and during the initial phase of the franchise"; and $(f)$ "other payments that the franchisee must make to begin operations." North American Securities Administrators Association (2000). 
Table 1. Variable Definitions

\begin{tabular}{|c|c|}
\hline Variables & Definition \\
\hline Dependent variable: Arb & $\begin{array}{l}\text { Dummy variable equaling one if the franchise agreement } \\
\text { contains arbitration clause }\end{array}$ \\
\hline \multicolumn{2}{|l|}{ Independent variables: } \\
\hline Hext (high externality) & $\begin{array}{l}\text { Dummy variable equaling one if the franchise is in a } \\
\text { "high-externality" industry }\end{array}$ \\
\hline Hexf & High externality $\times$ number of 1998 franchises \\
\hline Stupcost (startup cost) & $\begin{array}{l}\text { Initial investment in the franchise required of the } \\
\text { franchisee (median of range) }\end{array}$ \\
\hline $\begin{array}{l}\text { Co98perc (percent company } \\
\text { owned) }\end{array}$ & $\begin{array}{l}\text { Number of company-owned outlets as a percentage of } \\
\text { total company-owned and franchised outlets in } 1998\end{array}$ \\
\hline Homebase & $\begin{array}{l}\text { Dummy variable equaling one if the franchisor permits } \\
\text { the franchisee to operate franchise from home }\end{array}$ \\
\hline Parttime & $\begin{array}{l}\text { Dummy variable equaling one if the franchisor permits } \\
\text { the franchisee to operate franchise on a part-time basis }\end{array}$ \\
\hline Frsin (franchising since date) & The year the franchisor began franchising \\
\hline Inbs & The year the franchisor began doing business \\
\hline Puni (punitive damages) & $\begin{array}{l}\text { Dummy variable equaling one if the franchise agreement } \\
\text { restricts award of punitive damages }\end{array}$ \\
\hline Timelimi (time limit) & $\begin{array}{l}\text { Dummy variable equaling one if the franchise agreement } \\
\text { imposes a time limit for filing a claim }\end{array}$ \\
\hline Location & $\begin{array}{l}\text { Dummy variable equaling one if the franchise agreement } \\
\text { provides for litigation/arbitration to take place in the } \\
\text { state where the franchisor's home office is located }\end{array}$ \\
\hline Frgr (franchise growth rate) & $\begin{array}{l}\text { Percentage change in the number of franchises between } \\
1996 \text { and } 1998\end{array}$ \\
\hline Hoflit (home office litigation) & $\begin{array}{l}\text { Urbanization rate in the state where the franchisor's } \\
\text { home office is located }\end{array}$ \\
\hline Hofll & Hoflit $\times$ Location \\
\hline Frreg & $\begin{array}{l}\text { Dummy variable equaling one if the state in which the } \\
\text { franchisor's home office is located has enacted a } \\
\text { franchisee protection statute }\end{array}$ \\
\hline Fr98 & Number of franchisees in 1998 \\
\hline
\end{tabular}

term in the dispute resolution clause of the franchise contract. The "external variables" category consists of variables that measure external features over which the parties have no control, such as the litigiousness of the home office jurisdiction (Hoflit). In addition to Hoflit, the other external variables are Frreg and the interaction term Hofl. The "internal" category includes variables that describe descriptive features of the franchise relationship, such as the percentage of company-owned units (Co98perc). In addition to Co98perc, the other internal variables are Fr98, Frsin, Inbs, Stupcost, Homebase, Parttime, Frgr, Hext, and the interaction term Hexf.

Perhaps the only one of the independent variables that needs explanation is Frreg, the dummy variable coding for the existence of a franchisee protection stature in the state of the franchisor's home office. ${ }^{26}$

26. Instead of a dummy variable, it might be preferable to use as a variable the percentage of franchised units located in states with franchisee protection statutes. The data set we are using did not include such a variable, however. 
Purportedly to protect franchisees from opportunism, a number of states have enacted statutes to restrict the ability of franchisors to terminate franchisees. The statutes variously forbid termination other than for "cause" or permit the franchisee an opportunity to cure (Brickley, Dark, and Weisbach 1991).

The franchisee protection statutes differ, however, in scope of application. Some unambiguously apply only to in-state franchisees. Others by their terms apply to both in-state and out-of-state franchisees, although some courts have construed them more narrowly. ${ }^{27}$ To consider the effects of these differences, we split the Frreg variable into two new variables, FrregA and FrregB. The variable FrregA equals one when the franchisor is located in a state with a franchisee protection statute applicable only to in-state franchisees. The variable FrregB equals one when the franchisor is located in a state with a franchisee protection statute applicable to both in-state and out-of-state franchisees.

The average start date for businesses in the sample is 1964. The average date they began franchising is 1975 . The sample businesses had 2,331 franchise outlets and 401 company-owned outlets in 1998. The dummy variables describing the franchise contracts indicate that 34 firms had arbitration clauses, 55 had location clauses, 25 had time limit clauses, and 40 had punitive damages clauses. The numbers of homebased and part-time arrangements were 10 and 12 , respectively.

3.2.2. The Endogeneity Problem. We are using contract term variables in the regression equation for Arb in order to search for evidence that particular terms are either substitutes or complements to arbitration. However, one problem with using contract variables in a regression model in which Arb, another contract term, is the dependent variable is that the contract terms may be endogenous because they are jointly determined along with Arb. For example, most observers would assume that the decision to include an arbitration agreement (Arb) and the decision to include a clause limiting damages (Puni) would be influenced

27. The three states in which these types of statute appear are Michigan, Minnesota, and Wisconsin. However, in Minnesota and Wisconsin, federal district courts have held that the statutes apply only to in-state franchisees. The Minnesota case was decided after these data were collected. The $W$ isconsin case was decided before these data were collected. On this interpretation of the statutes, subdividing the Frreg variable is unnecessary. However, we subdivided Frreg on the theory that a franchisor in Michigan, Minnesota, or Wisconsin would be advised by counsel of the risk that a state or federal appellate court might hold that the state's franchisee protection statute applies to both in-state and outof-state franchisees and that this advice would affect the terms of the franchise agreement. 
by some of the same factors, though in different ways. If one were to simply include Puni in a regression equation in which Arb is the dependent variable, the error term would be correlated with Puni.

One approach to this would be to treat the contract term variables as if they are all endogenous and set up a four-equation "seemingly unrelated regressions" model using Arb, Puni, Location, and Timelimi as dependent variables and the internal and external variables as independent variables. However, this approach would not allow us to examine evidence of substitution between the arbitration clause and explicit contract terms. An alternative approach is to find instrumental variables for all of the contract term variables in the regression model. This is unworkable because our sample could not possibly yield a sufficient number of variables that could serve as instruments.

Our solution to this problem was to try to determine which contract variables seemed to be endogenous and to instrument for this subset. To do this, we ran a series of pairwise bivariate probit regressions using the four contract term variables as dependent variables and the other variables as independent variables. We examined the results for significant correlations across error terms. The only statistically significant correlation was that between the Arb and Puni regression equations. ${ }^{28} \mathrm{On}$ the basis of this result, we decided to use a single-equation model, with Arb as the dependent variable and using instruments for Puni. We treated the other contract term variables (Timelimi and Location) as exogenous, given the results of the bivariate probit regressions:

$$
\begin{gathered}
\operatorname{Arb}_{i}= \begin{cases}1 & \text { if } X_{i} \beta+\alpha \text { Puni }_{i}+\varepsilon_{i}>0, \\
0 & \text { otherwise, }\end{cases} \\
\operatorname{Puni}_{i}= \begin{cases}1 & \text { if } W_{i} \delta+v_{i}>0, \\
0 & \text { otherwise, }\end{cases} \\
\operatorname{cov}\left(\varepsilon_{i}, v_{i}\right) \neq 0,
\end{gathered}
$$

where the vector $X_{i}$ includes the exogenous variables of the Arb regression model and $W_{i}$ consists of the exogenous instruments for Puni. We

28. The maximum-likelihood method we used did not estimate the error correlation directly. If $\rho$ represents the error correlation, we estimated $\operatorname{atanh} \rho=\frac{1}{2} \ln [(1+\rho) /(1-\rho)]$. For the Arb and Puni equations, atanh $\rho=12.17$ ( $t$-statistic $=.03)$, and the hypothesis $\rho=0$ was rejected at the 1-percent significance level. For the Arb and Location pairing, atanh $\rho=.17$ ( $t$-statistic $=.71)$, and the hypothesis $\rho=0$ was not rejected (at the 1-, 5-, or 10-percent levels). For the Arb and Timelimi pairing, atanh $\rho=.23$ ( $t$-statistic $=1.04$ ), and the hypothesis $\rho=0$ was not rejected (at the 1-, 5-, or 10-percent levels). 
estimated the model by the maximum-likelihood method for the standard bivariate probit model.

3.2.3. Expected Signs of Regression Coefficients. To simplify our discussion of hypotheses, we will divide the independent variables used for the Arb regression into the three categories identified earlier: contract terms, internal, and external.

Contract Term Variables. We expect Timelimi, which codes for the existence of a clause limiting the time in which a claim may be filed, to have a negative coefficient. The reason is that if the parties have already agreed to a provision constraining litigation, the litigation cost or deterrence concerns that might lead them to prefer arbitration are lessened to some extent. In addition, since time limit agreements are common and pose no special enforcement problems in courts, the parties expect them to be enforced like any other explicit contractual term. Thus, the parties should be less likely to choose arbitration if they have agreed to time limits.

For the same reason, we expect a negative coefficient on Location, which codes for the existence of a clause selecting the franchisor's home state forum for litigation. If the parties have shown a preference for the home forum, particularly one in which juries are less likely to have a "deep pocket" view of franchisors, they should be less likely to opt for arbitration.

Both Timelimi and Location reflect the parties' interests in enhancing deterrence benefits and controlling dispute resolution costs. Time limits and venue specifications both reduce the likelihood of overdeterrence, and in this sense enhance the deterrence benefit associated with contract enforcement. Both also reduce dispute resolution costs. Dispute costs are obviously reduced by the imposition of time limits, since they cut off claims arising after the limit. Venue specification also reduces litigation costs by saving the franchisor the cost of having to litigate in many different jurisdictions and of having to bring the same set of witnesses to various states for trial. In addition, franchisees are less likely to sue in a forum that is less generous to plaintiffs.

We expect the coefficient on Puni to be positive. The existence of a clause limiting damages shows a big concern on the franchisor's part that a punitive damage award is a likely event in court. If the expected level of such an award exceeds the optimal damage level, the parties will have a joint incentive to agree to contractual limits on damages. Given this incentive, the parties will also have a joint incentive to choose 
the arbitration regime, since the deterrence benefit will be greater in the arbitration regime.

One might argue that our assumptions regarding Puni, on one hand, and Timilimi and Location, on the other, seem inconsistent. With the former set of variables, we argue that arbitration is more likely. With the latter variable, we argue that arbitration is less likely. What explains the difference? Both sets of variables reflect overdeterrence concerns. However, we think the Puni restrictions are more likely to serve as complements rather than substitutes to arbitration. This is because of the greater risk that contractual restrictions on punitive claims may not be enforced in court, and the greater potential loss to the franchisor in the event a court chooses not to enforce such restrictions. ${ }^{29}$ Given these risks, franchisors will seek arbitration in order to enhance the likelihood that restrictions on punitive damages claims will be enforced (Kobayashi and Ribstein 1999).

Internal variables. The term Co98perc should have a negative coefficient, because as the percentage of company-owned units increases in the network, the incentive divergence problem lessens. In part, this statement is tautological: the incentive divergence problem associated with franchising necessarily lessens as the degree of partial integration increases. However, to the extent that partial integration improves the monitoring capability of the franchisor, the shirking and free-riding problem should lessen even within the franchised units of a partially integrated network (Michael 2000, p. 2). Steven Michael argues that partial integration provides an additional bargaining power advantage to the franchisor, since the partially integrated franchisor has a more

29. We would lose little in remaining uncommitted about the signs of the coefficients on Puni, Timelimi, and Location and merely saying that we expect them to have a big impact. If we took this approach, we would allow the regression results to tell us whether the restriction served as a complement or substitute to arbitration. In any event, there is evidence supporting our argument that some state court judges would be reluctant to enforce punitive damage restrictions. A study of judicial decisions in Alabama finds that judges' votes on arbitration decisions are strongly correlated with the source of campaign funding (plaintiffs' lawyers or business); see Ware (1999). See also Ex Parte Thicklin (824 So. $2 \mathrm{~d} 723,733$ [Ala. 2002]) ("it violates public policy for a party to contract away its liability for punitive damages, regardless of whether the provision doing so was intended to operate in an arbitral or judicial forum"). 
credible threat to terminate the franchisee and replace it with an integrated unit. ${ }^{30}$

The coefficient on Parttime should be positive, since the problem of ensuring adequate effort is exacerbated in the case in which the franchisee works part-time. Given the greater likelihood of a dispute over effort levels, Parttime should be positively related to the probability of a dispute. Moreover, since the level of effort is difficult to specify and enforce contractually, the disputes associated with part-time status should be drawn heavily from those in which arbitration offers superior governance benefits relative to litigation. For the same reason, we expect Homebase to have a positive coefficient.

The coefficient on Stupcost, measuring startup costs, should be negative. If the startup cost variable is positively related to the franchisee's unrecoverable entry costs, a plausible assumption, then an increase in Stupcost implies a more credible termination threat on the part of the franchisor (Klein 1980; Klein and Saft 1985). Armed with a more credible sanction against shirking on effort, the franchisor will have greater confidence that the franchisee will comply with explicit and implicit contractual terms.

There is an alternative theory that also suggests that the coefficient on Stupcost should be negative. As the cost of entry increases, one expects both parties to rely more on explicit contractual terms. The franchisor would prefer to avoid the risk that it will be seen as terminating unfairly. The franchisee will prefer the security of knowing precisely what is required. Since both parties should prefer greater contractual explicitness as the startup cost gets larger, their demand for arbitration should fall, since they will write explicit contracts that can be entrusted to courts for enforcement.

The term Frgr, which measures growth of the franchise network between 1996 and 1998, does not have a clear sign under our theory. On one hand, network growth suggests increasing litigation expenses, which should push the parties toward the arbitration regime. On the other hand, a franchise that is growing fast may prefer to rely on explicit contracts, for several reasons. First, the fast-growing network may not have established reputation, in which case contractual explicitness will

30. Michael (2000). Michael's paper is concerned with "tapered integration," which occurs when the franchisor itself supplies some portion of the franchisee's inputs and some portion of the output is sold to the franchisor. However, his paper includes a thorough discussion of the effects of partial integration. 
substitute for reputation. Second, the fast-growing network, even if well established, may wish to use explicitness as a form of tying its hands, to assure the franchisee that the risk of arbitrary termination or expropriation is small. These arguments suggest that Frgr may have either a positive or negative coefficient, depending on whether the litigation cost factor outweighs the governance factor.

The variable Frsin, which measures the date at which the business began franchising, does not have an obvious coefficient sign under the theory of this paper. The same goes for Inbs, which measures the date at which the business began. On one hand, one might expect it to be negative, on the theory that a firm that enters the business late will have to rely on explicit contractual terms to substitute for reputation, and contractual explicitness implies a lower demand for arbitration. On the other hand, if the likelihood of a dispute is high, a newcomer may have a strong demand for arbitration, both for its deterrence benefits and to reduce dispute costs.

As one should expect, Frsin and Inbs are strongly correlated, with a coefficient of .48. Because of this, we decided not to use both in the regression equation for Arb. We settled on using Inbs in the regression equation for Arb, and Frsin as an instrument for Puni.

The term Hext appears by itself and interacted with Fr98 (recall that Hexf $=$ Fr $98 \times$ Hext). This makes interpretation of the Hext coefficient complicated. The Hext variable is equal to one when repeat business is low (and thus externalities are high). High-externality industries should be associated, other things being equal, with a greater likelihood of dispute. The interaction term Hexf can be understood as providing a volume-like measure of the externality problem. Alternatively, it can be understood as the product of the probability of a dispute and the cost of dispute resolution, since dispute costs will increase as the network size increases. This alternative view implies that Hexf is a proxy for the expected cost of dispute resolution.

We expect both Hext and Hexf to have positive coefficients. However, Hexf should have a much stronger effect, because it is a closer proxy of the expected cost of disputes. There are two reasons. First, the expected total cost of litigation increases as the franchise network expands, which suggests that arbitration is more likely as a means of reducing dispute resolution costs. Second, since the agency cost problem increases (other things being equal) with the size of the network, Fr98 should itself be positively related to the likelihood of a dispute for those franchises that get relatively little repeat business. 
What about the sign of Fr98? Again, this is complicated because it appears by itself and interacted with Hext in the regression. Examining the Fr98 variable coefficient alone, we expect it to capture the effect of expanding the number of networks in the low-externality setting. In this case the effects are unclear. On the one hand, arbitration remains useful as a means of cutting dispute resolution costs. On the other hand, as the network expands, the parties should have a greater demand for formality in contracts. Since monitoring is difficult, the franchisor wants to avoid a reputation for punishing arbitrarily, hence the need for explicit contracts. The franchisee should also prefer explicit contracts, given the lack of frequent contact with the franchisor's home office. ${ }^{31}$ Thus, in the low-externality case, we hypothesize that both litigation cost and deterrence motivations will be at work. The litigation cost factors push toward arbitration. The deterrence factors may push away from arbitration, since explicitness will lead the parties to keep their disputes in the courts. As a result, the expected sign of Fr98 is unclear.

External Variables. The sign on Frreg, the dummy variable coding for the existence of a franchisee protection statute, is unclear under the theory of this paper. Recall that protection statutes restrict the franchisor's power to terminate, often requiring proof of a good reason (that is, "cause"). Thus, a protection statute reduces the franchisor's bargaining power by weakening the credibility of its threat to terminate the franchise. The effects, however, are complicated because the franchisor should be able to maintain a credible threat to sanction (including termination) for the violation of an explicit provision of the franchise agreement. Hence, if franchisors generally respond to franchisee protection statutes by adopting more explicit terms in their contracts or by reducing the number of franchised units (Brickley, Dark, and Weisbach 1991), the protection statutes may be associated with a lower demand for arbitration. This implies a negative coefficient for Frreg. On the other hand, if franchisors expect favorable treatment under arbitration, in the sense that arbitrators are more likely to disregard franchisee protection statutes or to enforce their contract provisions,

31. This is consistent with the literature on information constraints and organizational form-see, for example, Stein and Masten (2000). Explicit contract terms "harden" information, allowing it to be transmitted with accuracy along a large hierarchical network. This theory suggests that one by-product of information hardening is a reduction in the demand for arbitration. 
protection statutes should increase their demand for arbitration. This implies a positive coefficient on Frreg.

Put another way, the franchisor's response to a protection statute will be to substitute toward the dispute resolution regime in which its threat to sanction is most credible. If the franchisee protection statute is interpreted in the same manner by arbitrators and judges, the franchisor should substitute toward structural and contractual incentive alignment devices-company-owned outlets and explicit contract terms. However, if arbitrators are more likely to enforce contract terms or to interpret franchisee protection statutes in a manner favorable to franchisors, the franchisor will prefer the arbitration forum.

The variable Hoflit, which proxies for the litigiousness of the franchisor's home office state, appears twice in the regression, once alone and the other time interacted with Location (recall that Hofll $=$ Hoflit $x$ Location). When Hoflit appears interacted with Location, the interacted variable measures the effect of litigiousness in the home office state when the parties have chosen to litigate in the home office state. When Hoflit appears alone, it measures the effect of home office state litigiousness when the parties have chosen not to litigate in the home office forum.

The coefficient on Hoflit should be negative. To see this, consider the case of parties that have chosen to avoid the home office state by resolving their disputes in another forum. Their potential savings from changing the venue are greater as the litigiousness of the home office state (which they have escaped) increases. Given this, they should have a lower demand for arbitration.

The coefficient on Hofll should be positive. To see this, consider the case of parties that have decided to allow litigation to occur in the home office state. The coefficient on the interaction variable Hofll should be positive, since these parties are more likely to choose arbitration if they have decided to allow litigation to occur in a litigious forum.

3.2.4. Choice of Instruments. The instrument panel for the Puni regression equation consists of external and internal variables that we thought would serve well as predictors of a punitive damages clause. For the internal variables, we used a 2-year lagged measure of the franchise size: Fr96 and Frsin. The variable Frsin seems intuitively to be a better instrument for the Puni regression than Inbs, because Frsin measures how long the franchisor has been involved in franchising. One would expect the franchisor's demand for a punitive damages clause to fall as the number 
of years it has been franchising increases, since trust and reputation constraints should gradually replace reliance on explicit terms, and this was confirmed. ${ }^{32}$

On the assumption that the litigiousness of the home office jurisdiction would affect the likelihood of a punitive damages clause, we created two new external variables as instruments for the Puni regression. One, Eljc, is a dummy variable equaling one if the judges in the home office state are elected. The other, Efh, is an interaction term equal to the product of Eljc, Frreg, and Hoflit. To be sure, Eljc is not a direct measure of litigiousness. However, if elected judges tend to vote in favor of the groups that fund their campaigns (Ware 1999), franchisors should prefer explicit caps on damages in order to protect themselves from pro-plaintiff judges.

\subsection{Results}

The probit regression results are shown in Table 2. For a sample with only 75 observations, the results are surprisingly strong, with 10 of the coefficients in Table 2 coming in statistically significant at the 5 -percent level. Of the statistically significant variables, all have the predicted signs, and most of the signs for the insignificant coefficient estimates accord with our predictions.

3.3.1. Deterrence Hypothesis. The results suggest that the deterrence concerns are an important determinant of the decision to commit disputes to arbitration and that deterrence factors have a greater impact than litigation cost factors. These claims are supported by several of the coefficient estimates in Table 2. First, note that one of the largest of the sharply estimated coefficients, Puni, has the sign predicted by the deterrence theory. To the extent the parties are concerned about the prospect of punitive awards in their jurisdiction, and to the extent these awards are perceived as generating overdeterrence costs, the parties are considerably more likely to opt for a predispute arbitration agreement.

Second, compare the coefficients on Location and Timelimi. Both variables measure efforts by the parties to control the amount and type of litigation in order to reduce overdeterrence costs. Both coefficients have the predicted signs, which indicates that an arbitration agreement is less likely when the parties have made efforts to control litigation. Note also the positive coefficient estimate for Hofll (interacting Hoflit

32. We do not report the results of the Puni regression below. The coefficient on Frsin in that regression was positive, showing that the shorter the relationship, the more likely a punitive clause (coefficient $=.016, t$-statistic $=1.79$ ) . 
Table 2. Probit Regression Results

\begin{tabular}{|c|c|c|c|c|c|}
\hline Variable & Coefficient & $\begin{array}{c}\text { Marginal } \\
\text { Effect }\end{array}$ & $\begin{array}{c}\text { Coefficient } \\
\text { SE }\end{array}$ & $t$-Statistic & $\begin{array}{c}\text { Significance } \\
\text { Level }\end{array}$ \\
\hline \multicolumn{6}{|c|}{ Contract terms: } \\
\hline Location* & -6.268 & -.978 & 2.933 & -2.14 & .033 \\
\hline Timelimi $^{+}$ & -.739 & -.258 & .412 & -1.79 & .073 \\
\hline Puni ${ }^{*}$ & 3.511 & .887 & .658 & 5.33 & .000 \\
\hline \multicolumn{6}{|c|}{ External variables: } \\
\hline Frreg* & -1.354 & -.453 & .531 & -2.55 & .011 \\
\hline Hoflit* & -.076 & -.028 & .031 & -2.41 & .016 \\
\hline Hofll* & .082 & .031 & .039 & 2.11 & .035 \\
\hline \multicolumn{6}{|c|}{ Internal variables: } \\
\hline Inbs & -.002 & -.001 & .009 & -.26 & .799 \\
\hline Fr98* & -.0005 & -.0002 & .0003 & -1.94 & .052 \\
\hline Co98perc* & -.989 & -.371 & .280 & -3.53 & .000 \\
\hline Stupcost ${ }^{*}$ & -.001 & -.0004 & .0004 & -2.55 & .011 \\
\hline Homebase & .143 & .055 & .642 & .22 & .823 \\
\hline Parttime $^{+}$ & 1.743 & .603 & .918 & 1.90 & .058 \\
\hline Frgr* & -.308 & -.115 & .093 & -3.29 & .001 \\
\hline Hext & -.726 & -.268 & .485 & -1.50 & .134 \\
\hline Hexf* & .0006 & .0002 & .0002 & 2.23 & .026 \\
\hline Constant & 10.358 & & 18.565 & .56 & .577 \\
\hline
\end{tabular}

Note. Bivariate Probit using Arb as dependent variable. Instrument panel for Puni: Eljc, Fr96, Frsin, Efh. Marginal effects for Frreg, Location, Timelimi, Parttime, Hext, and Homebase are based on a discrete change of the dummy variable from zero to one. Number of observations $=75 ; \log$ likelihood $=-75.956 . \mathrm{SE}=$ standard error.

+ Significant at the $10 \%$ level.

- Significant at the $5 \%$ level.

and Location), which indicates that the parties are more likely to choose arbitration if they have already chosen to resolve their disputes in a litigious home office state.

Location should be relatively more sensitive to deterrence concerns than Timelimi, since the location choice will often be used to avoid litigious jurisdictions. The fact that the Location coefficient is larger than that for Timelimi can be viewed, under this hypothesis, as further support for the claim that deterrence concerns appear to dominate litigation cost concerns in the decision to opt for a predispute arbitration agreement.

Third, and most striking, the coefficient estimates on Co98perc and Stupcost are both negative and significant, as predicted. The Co98perc estimate indicates that as the percentage of company-owned units increases the demand for arbitration falls. This is consistent with the view that as Co98perc increases, the fundamental incentive divergence problem in franchising becomes less severe. As this happens, the deterrence benefits from arbitration fall, and arbitration becomes less attractive. The Stupcost estimate indicates that as the franchisee's setup cost increases, the demand for arbitration falls. This is consistent with 
the view that the incentive divergence problem lessens as the franchisor's bargaining power increases.

The positive coefficient on Parttime is consistent with the prediction that arbitration is more likely when it is hard to specify and enforce implicit contractual terms, as is the case with franchisee effort. Since it is difficult to monitor the effort of franchisees that work part-time or at home, the franchisor must rely on legal sanctions in order to encourage a high level of effort. Since arbitration offers the advantage of review by an expert panel (alternatively, a panel with superior incentives for accuracy), enforcement is more predictable, enhancing deterrence. That the coefficient for Parttime is significant, while that for Homebase is not, suggests that the monitoring issue is especially important for parttime franchisees.

The network size coefficient estimates suggest complicated effects. The negative coefficient on $\mathrm{Fr} 98$ indicates that the parties are less likely to choose arbitration as the size of the network increases. However, the coefficient on Hexf, interacting Hext and Fr98, is positive. The two results in combination suggest that for low-externality (equivalently, high-repeat-customer) businesses, franchise scale is negatively associated with the likelihood of arbitration. For high-externality businesses, franchise scale is positively associated with arbitration. The latter result is intuitive: disputes are more likely in high-externality businesses, thus arbitration should be preferred as a means of both reducing litigation expenses and enhancing deterrence. The negative coefficient on Fr98 suggests that in low-externality settings, the parties are more likely to rely on explicit contract terms, easily enforceable in court, to govern the relationship as the network expands. This reduces their demand for arbitration.

The results for network size also lend support to the notion that deterrence enhancement rather than the litigation cost reduction is the dominant motivation behind arbitration. If litigation cost reduction were the major motivation behind arbitration, one should expect to see a positive relationship between network size and arbitration, even in the case of low-externality businesses. However, the negative coefficient suggests that the litigation cost savings are not sufficient to entice the parties to forgo the deterrence benefits secured by the option to litigate in ordinary courts. After all, ordinary courts have an established set of legal precedents on which the parties can rely and use to predict the outcomes of potential disputes. These results suggest that the litigation 
cost savings must be quite large for the parties to choose to forgo these advantages.

3.3.2. Contractual Substitutes and Complements to Arbitration. The variable Frreg has a negative and statistically significant coefficient. The estimated marginal effect suggests that if you compare similar franchisors, one based in a state with a franchisee protection statute and the other not, the probability of an arbitration agreement is lower by .45 for the franchisor based in the state with the protection statute.

At a minimum, this result suggests that franchisors have not viewed arbitration as a forum in which arbitrators would disregard or misapply franchise protection statutes to benefit franchisors. All else equal, franchisors located in states with no franchise protection statute are more likely to provide for arbitration than other franchisors. The result suggests that franchisors have responded to franchisee protection statutes by reducing franchised units and substituting toward explicit contractual terms, both reducing the demand for arbitration. To the extent the negative coefficient reflects structural responses (reductions in the number of units, home office location choices), it is consistent with the results of Brickley, Dark, and Weisbach's study of franchise termination statutes. ${ }^{33}$ However, since we have controlled for the key structural response, the percentage of company-owned units (Co98perc), ${ }^{34}$ we view the negative coefficient on Frreg as reflecting substitution toward explicit terms that are likely to be enforced in court.

Table 3 presents the results after splitting the Frreg variable into FrregA (for statutes limited solely to in-state franchisees) and FrregB (for statutes applicable by their terms to both in-state and out-of-state franchisees). The negative relationship appears to be stronger for FrregA

33. Brickley, Dark, and Weisbach (1991) find evidence that franchisee protection statutes cause a small reduction in the number of franchised units in settings where repeat business is low.

34. In light of the weak structural response found in Brickley, Dark, and Weisbach (1991), one might think that a superior approach to estimating the Co98perc coefficient (and Frreg) would be to separate its effect in states that have franchisee protection laws and those that do not. In order to this, we ran a version of the regression in Table 2 interacting Co98perc and Frreg. The interaction term came in insignificant, and the new estimates for Co98perc and Frreg, though slightly smaller in absolute value, were close to the estimates reported in Table 2. 
Table 3. Probit Regression Results after Splitting Frreg into FrregA and FrregB

\begin{tabular}{|c|c|c|c|c|c|}
\hline Variable & Coefficient & $\begin{array}{c}\text { Marginal } \\
\text { Effect }\end{array}$ & $\begin{array}{c}\text { Coefficient } \\
\text { SE }\end{array}$ & $t$-Statistic & $\begin{array}{c}\text { Significance } \\
\text { Level }\end{array}$ \\
\hline \multicolumn{6}{|c|}{ Contract terms: } \\
\hline Location $^{+}$ & -5.643 & -.974 & 3.133 & -1.80 & .072 \\
\hline Timelimi & -.664 & -.225 & .437 & -1.52 & .129 \\
\hline Puni* & 3.585 & .882 & .686 & 5.22 & .000 \\
\hline \multicolumn{6}{|c|}{ External variables: } \\
\hline FrregA & -1.953 & -.484 & .690 & -2.83 & .005 \\
\hline FrregB & -.955 & -.280 & .614 & -1.56 & .120 \\
\hline Hoflit $^{+}$ & -.064 & -.023 & .036 & -1.78 & .076 \\
\hline $\mathrm{Hofll}^{+}$ & .072 & .026 & .042 & 1.72 & .085 \\
\hline \multicolumn{6}{|c|}{ Internal variables: } \\
\hline Inbs & -.002 & -.0007 & .010 & -.19 & .848 \\
\hline $\operatorname{Fr} 98^{*}$ & -.0006 & -.0002 & .0003 & -2.11 & .035 \\
\hline Co98perc" & -1.070 & -.387 & .297 & -3.59 & .000 \\
\hline Stupcost ${ }^{*}$ & -.001 & -.0004 & .0005 & -2.61 & .009 \\
\hline Homebase & .182 & .068 & .620 & .29 & .768 \\
\hline Parttime* & 1.627 & .581 & .660 & 2.46 & .014 \\
\hline Frgr ${ }^{*}$ & -.307 & -.111 & .081 & -3.80 & .000 \\
\hline Hext & -.812 & -.289 & .511 & -1.59 & .112 \\
\hline Hexf* & .0007 & .0002 & .0003 & 2.40 & .016 \\
\hline Constant & 8.913 & & 20.585 & .43 & .665 \\
\hline
\end{tabular}

Note. Bivariate probit using Arb as dependent variable. Instrument panel for Puni: Eljc, Fr96, Frsin, Efh. Marginal effect for FrregB is statistically significant at the $5 \%$ level. Marginal effect for Hext is significant at the $10 \%$ level. Number of observations $=75$; $\log$ likelihood $=-74.727 . \mathrm{SE}=$ standard error.

+ Significant at the $10 \%$ level.

* Significant at the $5 \%$ level.

than for FrregB, although testing for the equality of coefficients fails to reject the hypothesis that the coefficients are equal. ${ }^{35}$

35. Although the difference between the FrregA and FrregB coefficients is not statistically significant, the larger coefficient estimate for FrregA seems to confound the main result. What might explain the larger coefficient for FrregA? We can offer three possible explanations (keeping in mind that the difference is not statistically significant). First, the result could be due to a "composition effect," which would hold if most firms in the sample have most of their franchise outlets within the home state of the franchisor or close to it. In the Midwest, for example, a large percentage of the states have franchisee protection statutes (Minnesota, Illinois, Michigan, Wisconsin, Missouri). Any franchise operating in the Midwest would most likely find itself constrained by franchise regulation statutes in its home state and in nearby states. Second, there could be a "penalty effect" that results from a perception that an arbitration clause might lead to heavier scrutiny by home-state regulators. Thus, franchisors that reside in regulated states would be the most reluctant to demand an arbitration clause. Third, the negative coefficient may reflect substitution choices by contracting parties based in states that do not have franchisee protection statutes. If those parties prefer arbitration in order to minimize the likelihood of falling under the 
Table 4. Elasticities

\begin{tabular}{lc}
\hline Variable & Elasticity \\
\hline Fr98 & -1.22 \\
Stupcost & -.33 \\
Co98perc & -.31 \\
Hoflit & -5.90 \\
Frgr & -.16 \\
Hofll & 4.60 \\
Hexf & .77 \\
\hline
\end{tabular}

3.3.3. Comparing Deterrence Effects. In order to make a better comparative assessment of the coefficient estimates, we converted those for the continuous variables into elasticities. The results are presented in Table 4 (based on estimates in Table 2). The largest elasticity, -5.9 , is that for Hoflit, the proxy for litigiousness in the home office jurisdiction. Recall that we use the state urbanization rate as the proxy for litigiousness. The estimate indicates that a 1-percent increase in the urbanization rate of the home office state reduces the demand for arbitration among those who have not opted to litigate inside the home jurisdiction by almost 6 percent. This large elasticity makes sense if we read this as indicating the extent to which parties are using venue specification to opt out of high-litigation jurisdictions. After opting out of such jurisdictions, the parties apparently see little need to precommit to arbitration.

The large elasticity on Hoflit provides yet another piece of support for the claim that the deterrence theory provides the strongest account of the motivation for arbitration. We have argued that contracting parties opt out of high-litigation jurisdictions in order to reduce overdeterrence costs. They have a joint incentive to do so, since overdeterrence costs are shared between them. After opting out of a high-litigation forum, the key remaining motivation for choosing arbitration over litigation is the desire to reduce dispute resolution costs. However, the large negative elasticity on Hoflit, which implies that the parties do not have a strong demand for arbitration once they have escaped a high-litigation forum, suggests that the motivation to reduce dispute costs is not strong. Conversely, the large positive elasticity on Hofll suggests that among those parties that have not opted out of the

franchisee protection statute of another state, we could observe the result in Table 2. However, we find this explanation less likely, since the parties could include more cheaply a choice-of-law clause to the same effect. If, however, arbitrators are more likely to enforce such choice-of-law clauses than courts, the results here could nonetheless follow. 
home office forum, a 1-percent increase in litigiousness leads to a nearly 5 -percent increase in their demand for arbitration.

The other elasticity estimates are dwarfed by the location measures, but they still reveal interesting information. A 1-percent increase in network size reduces the demand for arbitration by 1.2 percent in the low-externality setting and increases the demand for arbitration by roughly .8 percent in the high-externality setting. Two variables that the franchisor controls, the percentage of company-owned units and the franchisee's startup cost, have different impacts on the probability of arbitration. A 1-percent increase in the startup cost reduces the probability of arbitration by .33 percent, while a 1 -percent increase in the percentage of company-owned units reduces the probability by .3 percent. This suggests that when choosing between the two instruments, the franchisor should have an incentive to increase the startup cost in order to control franchisee incentives.

\subsection{Overview of Results}

The central claim of this paper is that contracting parties will choose the dispute resolution forum that maximizes the deterrence or governance benefits associated with their contract net of dispute resolution costs. The deterrence benefit from contract enforcement is the sum of harms avoided net of avoidance costs. Since arbitration clearly has the potential to reduce dispute resolution costs, the key contribution of this study is its demonstration of the relative importance of deterrence factors in the arbitration decision.

Holding dispute resolution costs fixed, parties will structure their contract so that future disputes are resolved within the forum that provides the optimal level of deterrence against undesirable conduct. Thus, if expected damages in court exceed or fall below the optimal level, and expected damages under arbitration are closer to the optimal level, they will have an incentive to commit to arbitration. For disputes involving implicit contractual terms the parties will prefer arbitration, provided the arbitration forum is the more accurate one for dispute resolution. As the probability of a dispute increases, their preference for committing disputes over implicit terms to arbitration should increase.

The results of this paper support these implications of the deterrence hypothesis. Franchising parties who include provisions in their contracts limiting damages-those most concerned about the risk of excessive damages in court-are highly likely to opt for arbitration. Among the parties who have chosen to opt out of a litigious jurisdiction by specifying 
an alternative venue, a 1-percent increase in the litigiousness (measured by urbanization rate) of the home office jurisdiction reduces the probability of arbitration by 6 percent. Factors suggesting a potentially greater reliance on explicit contractual terms, such as the existence of a franchisee protection statute, substantially reduce the probability of an arbitration agreement. Factors that increase the credibility of the franchisor's termination threat, such as an increase in franchisee startup costs or in the percentage of company-owned units, reduce the probability of arbitration.

Although the desire to reduce dispute resolution costs is an obvious motivation to commit to arbitration, the results here suggest that deterrence issues matter more than dispute costs. For example, for those franchise networks in which individual units enjoy a relatively high degree of repeat business, an increase in network size is associated with a reduction in the probability of arbitration. This suggests that among these franchises, the desire to reduce dispute costs is not strong enough to induce them to forgo the governance benefits already provided by courts.

\section{CONCLUDING REMARKS}

This paper demonstrates the importance of deterrence concerns in the decision of contracting parties to choose to resolve their disputes in arbitration rather than through litigation. The hypothesis examined is that contracting parties will choose the dispute resolution forum in which the difference between deterrence benefits, defined as avoided harms net of avoidance costs, and dispute resolution costs is the largest. The results support this hypothesis and provide an illustration of the importance of deterrence factors. Indeed, this has to be viewed as the central contribution of this paper, since everyone knows that contracting parties have an incentive to minimize dispute resolution costs. This is the first empirical analysis to demonstrate the relative importance of deterrence factors in the decision to choose a dispute resolution forum. The results suggest that deterrence concerns play the dominant role in this decision.

The importance of deterrence concerns has several implications for public policy issues, which we will only briefly mention here. First, there is a common view that arbitration involves a weaker party selling his legal rights to a stronger party (repeat-player firm), sometimes in a coercive setting. The coercion claim is weak in the franchising context, 
since the both parties are businesses that consult with lawyers. Moreover, the parties have a mutual incentive to choose the dispute resolution forum that delivers the greatest deterrence benefit per dollar invested in dispute resolution. Arbitration may weaken some legal rights, if viewed as rights to sue in court, and enhance others, as when the arbitration regime provides the more accurate forum for dispute resolution. In any event, the overall result should enhance the welfare of both contracting parties.

There is also a common view that firms use arbitration to avoid the application of mandatory laws. The results here are inconsistent with this view. Franchisors located in states with franchisee protection statutes have less demand for arbitration than other franchisors, which does not support the claim that businesses seek arbitration in order to evade the effects of mandatory laws. We hypothesize that franchisors have responded to the deterrence-diluting effect of protection statutes by substituting toward explicit contractual terms.

Finally, the importance of deterrence concerns suggests that laws that make arbitration less attractive, such as franchisee protection statutes, have substantial wealth effects. Such statutes not only raise the costs of dispute resolution, but they also reduce the governance benefits associated with a contract. Since the governance benefits affect such day-today matters as the quality of output and the level of effort, the total costs of protection statutes are likely to be far larger than their effects on dispute resolution costs.

\section{REFERENCES}

Bernstein, Lisa. 1996. Merchant Law in a Merchant Court: Rethinking the Code's Search for Immanent Business Norms. University of Pennsylvania Law Review 144:1765-1821.

Brickley, James A. 1999. Incentive Conflicts and Contractual Restraints: Evidence from Franchising. Journal of Law and Economics 42:745-74.

Brickley, James A., and Frederick H. Dark. 1987. The Choice of Organizational Form: The Case of Franchising. Journal of Finance and Economics 18: 401-20.

Brickley, James A., Frederick H. Dark, and Michael S. Weisbach. 1991. The Economic Effects of Franchisee Termination Laws. Journal of Law and Economics 34:101-32.

Drahozal, Christopher R. 2000. Commercial Norms, Commercial Codes, and 
International Commercial Arbitration. Vanderbilt Journal of Transnational Law 33:79-146.

- 2001. "Unfair" Arbitration Clauses. University of Illinois Law Review 2001:695-790.

Entrepreneur Magazine. 1999a. 20th Annual Franchise 500. January.

- 1999b. Understanding the Franchise 500. January.

-1999c. The Wonder Years: A Look at How Franchising and the Franchise 500 Have Changed over the Past 20 Years. January.

Federal Trade Commission. 1999. State Agencies Administering Franchise

Disclosure Laws. http://www.ftc.gov/bcp/franchise/netdiscl.htm (last updated June 16, 1999).

Hadfield, Gillian K. 1990. Problematic Relations: Franchising and the Law of Incomplete Contracts. Stanford Law Review 42:927-92.

Hylton, Keith N. 2000. Agreements to Waive or to Arbitrate Legal Claims: An Economic Analysis. Supreme Court Economic Review 8:209-63.

. 2002. Welfare Implications of Costly Litigation under Strict Liability. American Law and Economics Review 4:18-43.

Klein, Benjamin. 1980. Transaction Cost Determinants of "Unfair" Contractual Arrangements. American Economic Review Papers and Proceedings 70 : 356-62.

Klein, Benjamin, and Lester F. Saft. 1985. The Law and Economics of Franchise Tying Contracts. Journal of Law and Economics 28:345-61.

Kobayashi, Bruce H., and Larry E. Ribstein. 1999. Contract and Jurisdictional Freedom. In The Fall and Rise of Freedom of Contract, edited by $\mathrm{F} . \mathrm{H}$. Buckley. Durham, N.C.: Duke University Press.

Lafontaine, Francine, and Emmanuel Raynaud. 2002. The Role of Residual Claims and Self-Enforcement in Franchise Contracting. In The Economics of Contracts: Theories and Applications, edited by Eric Brousseau and JeanMichel Glachant. Cambridge: Cambridge University Press.

Lafontaine, Francine, and Kathryn Shaw. 1999. The Dynamics of Franchise Contracting: Evidence from Panel Data. Journal of Political Economy 107: 1041-80.

Macneil, Ian R. 1978. Contracts: Adjustment of Long-Term Economic Relations under Classical, Neoclassical and Relational Contract Law. Northwestern University Law Review 72:854-905.

Mathewson, G. Frank, and Ralph A. Winter. 1985. The Economics of Franchise Contracts. Journal of Law and Economics 28:503-26.

Michael, Steven C. 2000. Investments to Create Bargaining Power: The Case of Franchising. Working Paper No. 99-0126, University of Illinois UrbanaChampaign.

North American Securities Administrators Association. 2000. The Uniform Franchise Offering Circular: Guidelines. http://www.nasaa.org/nasaa/scripts/ fu_display_list.asp?ptid $=34$ (visited June 19, 2003). 
Park, William W. 1998. Arbitration in Banking and Finance. Annual Review of Banking Law 17:213-85.

Polinsky, A. Mitchell, and Daniel L. Rubinfeld. 1988. The Welfare Implications of Costly Litigation for the Level of Liability. Journal of Legal Studies 17: 151-64.

Posner, Richard A. 1997. Explaining the Variance in the Number of Tort Suits across U.S. States and between the United States and England. Journal of Legal Studies 26:477-89.

Rubin, Paul H. 1978. The Theory of the Firm and the Structure of the Franchise Contract. Journal of Law and Economics 21:223-33.

Shavell, Steven. 1995. Alternative Dispute Resolution: An Economic Analysis. Journal of Legal Studies 24:1-28.

-1982. The Social Versus the Private Incentive to Bring Suit. Journal of Legal Studies 11:333-40.

Shleifer, Andrei. 1985. A Theory of Yardstick Competition. RAND Journal of Economics 16:319-27.

Stein, Jeremy C., and Scott E. Masten. 2000. Informational Production and Capital Allocation: Decentralized vs. Hierarchical Firms. Working Paper No. W7705, National Bureau of Economic Research. May. http://papers.ssrn .com/paper.taf?abstract_id $=232091$.

Tullock, Gordon. 1980. Trials on Trial: The Pure Theory of Legal Procedure. New York: Columbia University Press.

Ware, Steven J. 1999. Money and Politics and Jucicial Decisions: A Case Study of Arbitration Law in Alabama. Journal of Law and Politics 15:645-86.

Williamson, Oliver E. 1985. The Economic Institutions of Capitalism. New York: Free Press. 